\title{
Do Weeds From Seeds or Regrowth in Coexistence Periods Alter Biochemical and Yield Characteristics of Soybeans?
}

\author{
Ana Paula Rockenbach ${ }^{1}$, Mauro Antônio Rizzardi ${ }^{1}$, Adriana Favaretto ${ }^{1}$, Theodoro Schneider ${ }^{2}$ \\ $\&$ Andréa Michel Sobottka ${ }^{3}$ \\ ${ }^{1}$ Programa de Pós-Graduação em Agronomia, Universidade de Passo Fundo, Passo Fundo, Rio Grande do Sul, \\ Brazil \\ ${ }^{2}$ Curso de Agronomia, Universidade de Cruz Alta, Cruz Alta, Rio Grande do Sul, Brazil \\ ${ }^{3}$ Curso de Farmácia, Universidade de Passo Fundo, Passo Fundo, Rio Grande do Sul, Brazil \\ Correspondence: Ana Paula Rockenbach, Departament of Weed, Passo Fundo University, BR 285, Bairro São \\ José, CEP: 99052-900, Passo Fundo, Rio Grande do Sul, Brazil. E-mail: anapagronomia@yahoo.com.br
}

Received: April 3, $2019 \quad$ Accepted: May 22, $2019 \quad$ Online Published: July 15, 2019

doi:10.5539/jas.v11n10p264 URL: https://doi.org/10.5539/jas.v11n10p264

The research is financed by National Council for Scientific and Technological Development (CNPq).

\begin{abstract}
The objective of this study was to evaluate changes in soybean secondary metabolism and soybean yield components when subjected to coexistence periods with volunteer corn and established horseweed (Conyza spp.) regrowth. Two field experiments were conducted in the agricultural years 2015/2016 and 2016/2017 at Passo Fundo University, Passo Fundo, Rio Grande do Sul, Brazil. Experiment I was conducted in the agricultural year 2015/2016 in order to establish periods of coexistence between soybean and corn. The treatments consisted of two

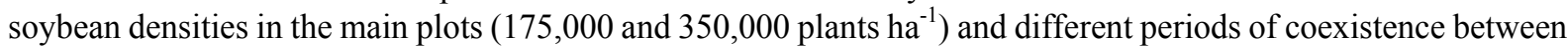
soybean and corn in the subplots. Experiment II was conducted in the agricultural year of 2016/2017 in order to investigate the interference of regrowth horseweed during coexistence periods with soybean. The total phenols, flavonoids, saponins, soybean yield components and seed yields were evaluated. Volunteer corn that initiates growth after the V4 soybean stage and horseweed regrowth during cultivation do not adversely affect secondary metabolism, seed yield or soybean yield components.
\end{abstract}

Keywords: competition, flavonoids, phenolic compounds, productivity, saponins

\section{Introduction}

The competition between weeds and crops is a type of negative interference where the organisms involved compete for the environment resources, light, nutrients and water. The degree of severity depends on factors such as species, density and distribution of weeds, crop cultivars, spacing and density, as well the environmental conditions and the period in which weeds interfer (Radosevich et al., 2007). The competition period is a determinant of the degree of interference, since weeds that emerge prior to or together with a crop have greater competitive potential than weeds that emerge later in the crop cycle. This is primarily due to the priority access to environmental resources (Piasecki, 2015; Tironi et al., 2014). Although the late weed emergence in relation to the crop development is less competitive in terms of yield, the weeds may be still problematic in terms of crop and seed quality (Swanton et al., 2015).

Morphological variables parameters, such as height, dry matter, and yield components, are normally used to determine the effects of plant competition (Piasecki, 2015; Tironi et al., 2014; Trezzi et al., 2015). In a few studies plant competition is investigated in relationship to changes in a species secondary metabolism (Silva et al., 2014). The secondary metabolism is directly related to plant's defense in response to environmental factors (Taiz \& Zeiger, 2013), which would include weed competition (Agostinetto et al., 2016; Broz et al., 2010; Gal et al., 2015; Silva et al., 2014). 
Crop seed yields are dependent on the crop's interaction with the management practices and production environment (Ribeiro et al., 2017). The greatest yields are obtained when the genotype has a high productive potential and adaptability to the environment, combined with the cultivation and management systems required by the crop (Mauad et al., 2010). The period of coexistence between crops and weeds is a determinant in the degree of interference imposed by competition on crop yield components. In soybeans, the largest yield reductions due to competition were with horseweed installed at 81 and 38 days before soybean planting (Trezzi et al., 2015). Among yield components, the number of pods is the most responsive to competition (Lamego et al., 2004; Trezzi et al., 2015).

Currently, deficiency in management practices, such as the lack of weed control before planting, allows the presence of weeds at the beginning of the crop development and allows regrowth of those that were cut before planting. In addition, a low plant density decrease the canopy closure time and increase weed emergence. Weed competition can result in significant crop yield reductions, therefore, it is important to evaluate the current soybean cultivation conditions, the weed impact on yield and yield components, and the secondary metabolites that are activated in adverse situations.

We hypothesized that weeds originating from seeds have a high potential to cause competition during the early stages of soybean development because, at a later stage, closing of the gap between crop rows makes it impossible for weed emergence due to lack of light. We also tested the hypothesis that regrowth horseweed plants have high potential for competition with the crop because they have a well-developed root system. The origin of weeds is of great importance in the degree of competition between weeds and a commercial crop, and will affect the coexistence periods, causing changes in the biochemical and soybean yield characteristics.

The objective of this study was to evaluate the changes in soybean secondary metabolism and yield components when subjected to periods of coexistence with volunteer corn and with regrowth of horseweed plants (Conyza spp.).

\section{Materials and Methods}

\subsection{Plant Materials and Growth Conditions}

Two field experiments were conducted in the agricultural years 2015/2016 and 2016/2017 at the Extension and Agricultural Research Center (CEPAGRO) at Passo Fundo University, Passo Fundo, Rio Grande do Sul, Brazil. The latitude coordinates were $28^{\circ} 13^{\prime} \mathrm{S}$, longitude of $52^{\circ} 23^{\prime} \mathrm{W}$ and approximate altitude was $700 \mathrm{~m}$ above sea level. The soil in the experimental area is classified as Humic Dystrophic Red Latosol (Streck et al., 2008). Rainfall and mean air temperature during the experimental period, as well as the climatological norms for the region, are presented in Figure 1. The meteorological conditions during the experiments were considered normal for the time of year.

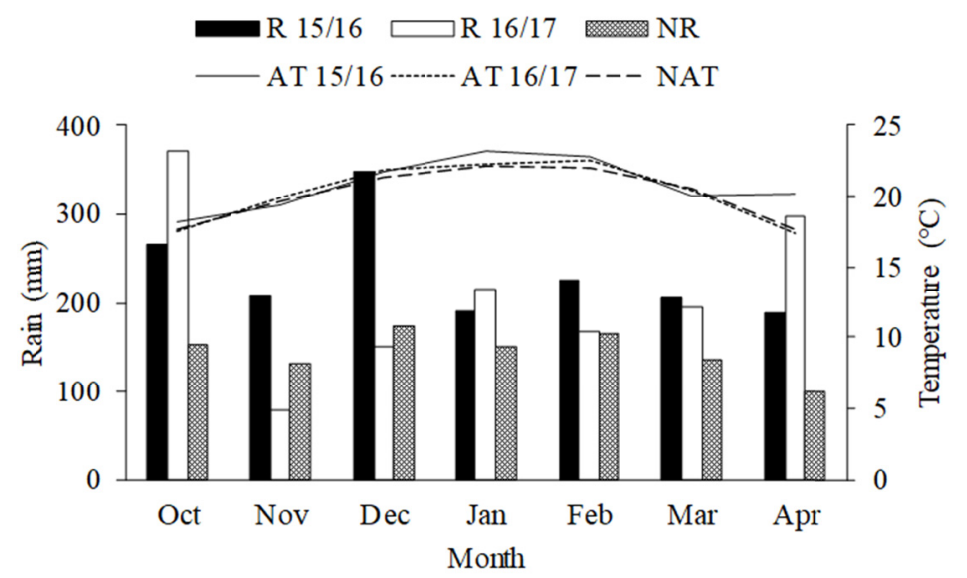

Figure 1. Rainfall (R), normal rainfall (NR), average temperature (AT) and normal average temperature (NAT) during the conduct of Experiments I and II. Passo Fundo, 2015-2016, 2016-2017

Source: Embrapa Trigo (2017). 
Experiment I was conducted in the agricultural year 2015/2016 in order to establish periods of coexistence between soybean and corn. Before the start of the experiment, glyphosate $\left(720 \mathrm{~g} \mathrm{ae} \mathrm{ha}^{-1}\right)$ and paraquat $\left(400 \mathrm{~g} \mathrm{ai} \mathrm{ha}^{-1}\right)$ were applied to the research area to control the existing weeds prior to planting. The soybean cultivar Pioneer 95R51, which has a growth cycle of 115 to 120 days, resistance to glyphosate and an indeterminate growth habit was used as the hybrid of Pioneer 32R22 YHR corn that shows resistance to the herbicide glyphosate (Pioneer, 2017).

By using corn as a weed, it was possible to define the density and the emergence season, as well as to facilitate the management of the other weeds during the soybean crop growth due to its resistance to glyphosate. Soybean sowing took place on October 28, 2015 at a spacing of $45 \mathrm{~cm}$ between rows. A commercial 4-24-18 (N, P, K) fertilizer, was applied at $350 \mathrm{~kg} \mathrm{ha}^{-1}$.

The experimental design was a randomized complete block design with four replications. The plots were 7 rows 45 $\mathrm{cm}$ apart of soybean $(3.5 \mathrm{~m})$ and $5 \mathrm{~m}$ long. The treatments consisted of two soybean densities in the main plots $\left(175,000\right.$ and 350,000 plants ha $\left.{ }^{-1}\right)$ and different periods of coexistence between soybean and corn in the subplots. The coexistence periods were as follows: V0-R8 (V0 was corn sown on the same day as soybean; V2-R8 (V2 was second node, first fully-developed trifoliolate leaf on soybean at the time of sowing of corn); V4-R8 (V4 fourth node, third fully-developed trifoliolate leaf on soybean on occasion of corn sowing), and where R8 was physiological maturation of soybean. The control soybean plants were grown without competition.

The sowing of the corn was at a density of 2 plants $\mathrm{m}^{-2}$ between the lines of the crop, realized with the aid of a manual seeder. This density was chosen to create a significant level of competition with soybean (Piasecki, 2015). During the experiment, phytosanitary management was carried out according to recommendations for the crop.

Experiment II was conducted in the agricultural year of 2016/2017 in order to investigate the interference of regrowth horseweed plants during coexistence periods with soybean. The experiment took place in a fallow area with the presence of large horseweed. On the first day of the experiment, horseweed plants were cut to height of 10 $\mathrm{cm}$ above the soil using a soybean harvester to stimulate their regrowth during the development of the crop.

Subsequently, treatment with glyphosate $\left(720 \mathrm{~g} \mathrm{ae} \mathrm{ha}^{-1}\right)$ was carried out to control other plant species. The soybean cultivar used was Pioneer 95R51, described above, which was sown on December 02, 2016 at a between-row spacing of $45 \mathrm{~cm}$ and a density of 350,000 plants ha ${ }^{-1}$. A commercial 04-24-18 (N, P, K) fertilizer, was applied at $350 \mathrm{~kg} \mathrm{ha}^{-1}$. Plant emergence at a level of 50\% occurred on December 09, 2016.

The experiment was conducted as a randomized complete block design with sub-divided plots and with four replications. The plots were 7 rows $45 \mathrm{~cm}$ apart of soybean $(3.5 \mathrm{~m})$ and $5 \mathrm{~m}$ long. The treatments consisted of management of the regrowth in the main plots (pluck-removed the horseweed plants) and (court-cut the regrowth horseweed plants). In the pluck, the crop remained free of the presence of weeds after the stage of regrowth withdrawal; and in the court, this was performed by leaving four leaves for competition for soil resources to continue after the management stage.

The subplots represented different periods of coexistence between horseweed and soybean plants. The coexistence periods were: V0-R2, V0-R3; V0-R4; V0-R5 and V0-R6, where V0 was the start of crop development and R2 was full bloom, R3 beginning of pod formation, R4 full pod, R5 beginning seed and R6 full or complete grain (Fehr \& Caviness, 1977). The control treatment was soybean grown without weeds. During the experiment, phytosanitary management was carried out according to recommendations for the crop.

\subsection{Evaluations}

For the evaluation of secondary metabolites (total phenols, flavonoids and saponins), three plants were collected per replicate of each treatment at the phenological stage R2 (full bloom) and R5 (beginning seed) in Experiment I, and at the end of each coexistence period in Experiment II. The samples were oven dried at $50{ }^{\circ} \mathrm{C}$ until reaching a constant weight. This temperature was chosen because there was no damage to the secondary metabolites. Subsequently, the samples were ground in a vegetable mill and stored in plastic bags in the dark until evaluation.

Total phenols and flavonoids were determined using the methodology of Josipovic et al. (2016) with modifications. Extraction was performed with $0.5 \mathrm{~g}$ of the ground plant material and $5 \mathrm{~mL}$ of methanol (containing $1 \% \mathrm{HCl}$ ) using ultrasound for 1 hour. The samples were then centrifuged for 5 minutes at $4{ }^{\circ} \mathrm{C}$ and $9000 \mathrm{rpm}$. The resulting solution was filtered through a $0.45-\mu \mathrm{m}$ filter membrane and the volume made up to $5 \mathrm{~mL}$. The extraction solution was kept in the dark during the procedures.

For analysis of total phenols, $0.2 \mathrm{~mL}$ of the extraction solution (reported above) was added to $0.1 \mathrm{~mL}$ of Folin-Ciocalteu reagent and $1.5 \mathrm{~mL}$ of distilled water. After 5 minutes, $0.4 \mathrm{~mL}$ of $\mathrm{Na}_{2} \mathrm{CO}_{3}(14 \%)$ was added and the volume was made up to $10 \mathrm{~mL}$. The solution was vortexed for a few seconds and then kept in the dark at room 
temperature for 30 minutes. After this period, the absorbance was measured in a visible spectrophotometer at a wavelength of $765 \mathrm{~nm}$; a reference blank was used. Total phenol content was calculated from a calibration curve constructed using gallic acid standard and expressed as gallic acid equivalents (EAG) $\mathrm{g}^{-1}$ dry matter (DM). The concentration of gallic acid used for the calibration curve was 0.002 to $0.01 \mathrm{mg} \mathrm{mL}^{-1}$.

To evaluate the flavonoid content, $4 \mathrm{~mL}$ of distilled water and $0.3 \mathrm{~mL}$ of $\mathrm{NaNO}_{2}(5 \%)$ were added to $0.5 \mathrm{~mL}$ of the above extraction solution. The resulting solution was vortexed for a few seconds and kept at room temperature for 5 minutes. Thereafter, $0.3 \mathrm{ml}$ of $\mathrm{AlCl}_{3}(10 \%)$ was added, vortexed again and the solution was then kept at room temperature for another 5 minutes. Subsequently, $2 \mathrm{~mL}$ of $\mathrm{NaOH}(1 \mathrm{M})$ and $2.4 \mathrm{~mL}$ of distilled water were added. The absorbance was immediately read in a spectrophotometer at $510 \mathrm{~nm}$ using a reference blank. The total flavonoid content was calculated from a calibration curve using rutin as the reference substance and expressed as rutin (RUT) $\mathrm{g}^{-1} \mathrm{DM}$. To construct the calibration curve, rutin was used at concentrations of 0.01 to $0.08 \mathrm{mg} \mathrm{mL}^{-1}$.

The saponins were determined using the foam index technique, where $1 \mathrm{~g}$ of the plant material was extracted by decoction with $50 \mathrm{~mL}$ of distilled water for 30 minutes, then filtered into a 100-mL volumetric flask and made up to volume distilled water. This decoction was transferred to test tubes of equal size in a series of volumes $(1,2,3$ to $10 \mathrm{~mL}$ ). The volume of liquid in each tube was adjusted to $10 \mathrm{~mL}$, with further shaking for 15 seconds. After a 15-minute resting period, foaming was observed and the height of the foam was measured. Thus, the afrosimetric index was calculated by the equation 1000/A, where A is the volume $(\mathrm{mL})$ of the decoction used to prepare the dilution in the tube where the foam was observed (Farmacopéia, 2010).

For the evaluation of grain yield components at the maturation stage, ten plants were collected per replicate and the total number of pods, total seed and weight of one thousand seeds were determined. To determine the seed yield from the plots, plants were harvested from three central rows, each of four meters in length. After, the individually sample was weighed and measured, the sample weight was corrected to $13 \%$ moisture.

\subsection{Statistical Analysis}

Secondary metabolite data from Experiment I and yield components from both experiments were subjected to analysis of variance using the F-test $(\leq 0.05)$, and when significant, Tukey's comparison of means was performed. The secondary metabolite data from Experiment II were analyzed by the t-test $(\leq 0.05)$. For these data, the analysis was used through the t-test, since the plants were collected at different times.

\section{Results and Discussion}

The results for total phenols (R2 and R5) and flavonoids (R5) indicated no interaction between soybean plant density and coexistence periods in Experiment I (Figures 2 and 3). Also, the density of soybean plants had no effect on these variables (Figure 2). However, for the coexistence periods, with the R2 collection, increase in the total phenol content was observed when competition from weeds started in V2, but did not differ from V4 or the control. For the period of coexistence that started on the same day as soybean sowing, a lower content of total phenols was observed but without differing from the periods initiated in V4 or the control (Figure 3).

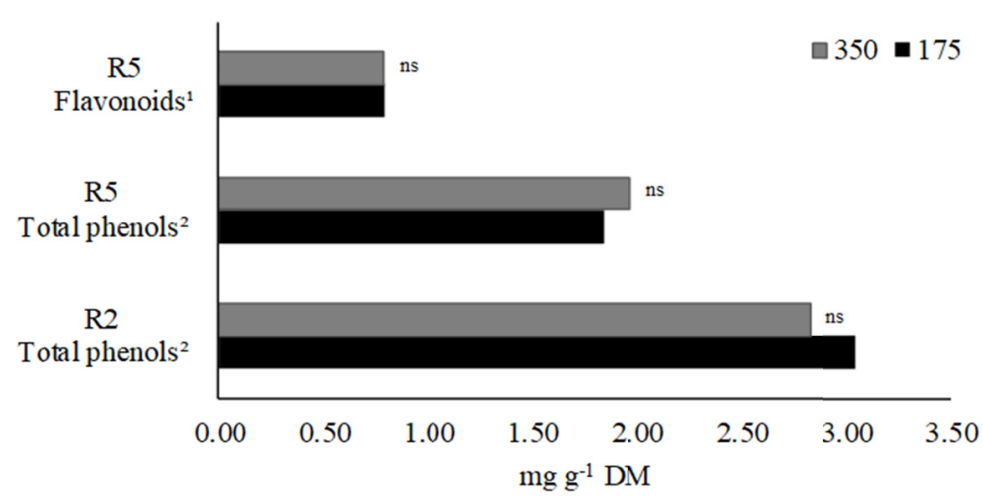

Figure 2. Total phenols and flavonoids in soybean plants with soybean cultivation densities (350 and 175 thousand plants $\mathrm{ha}^{-1}$ ) at stages R2 and R5

Note. ${ }^{1} \mathrm{mg}$ RUT g ${ }^{-1} \mathrm{DM}$; RUT: rutin; ${ }^{2} \mathrm{mg}$ EGA g ${ }^{-1}$ DM; EGA: equivalents of gallic acid; DM: dry matter; ${ }^{\text {ns }}$ : not significant. 
When the flavonoids were evaluated in the R2 stage, an interaction between soybean density and coexistence periods was observed, where the higher flavonoid content, occurred in the competition started in V2 with both densities, although it did not differ from the other treatments (Table 1). It was observed that the period of coexistence that started on the day of soybean sowing decreased the content of flavonoids in the collection at R2 with both densities. In the evaluation in R5, the flavonoid contents were similar between the different periods of coexistence (Figure 3).

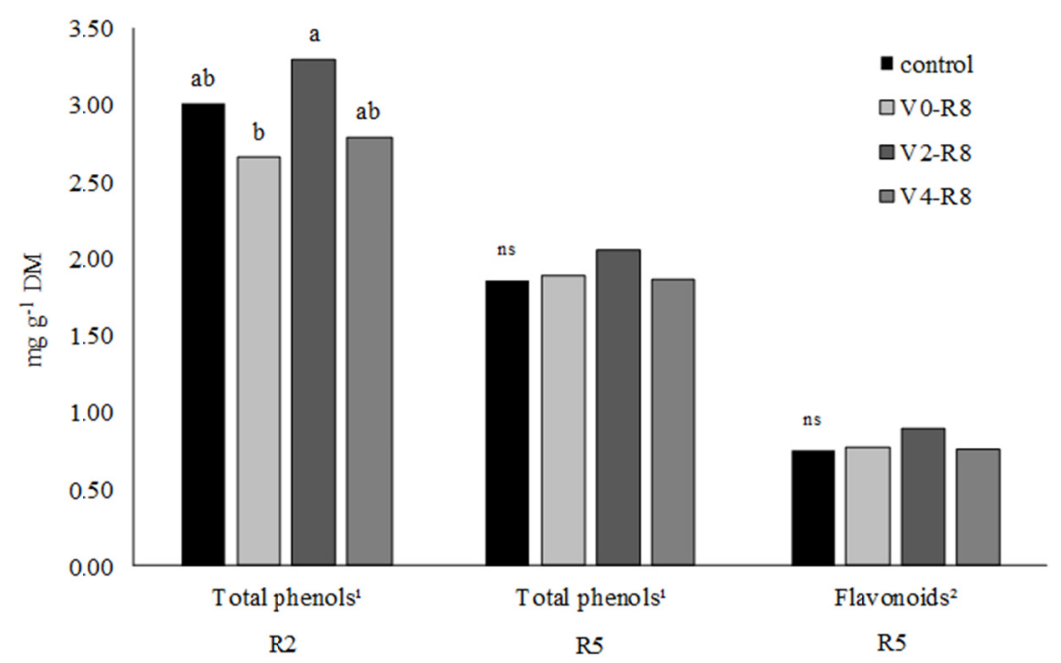

Figure 3. Total phenols and flavonoids of soybean plants submitted to coexistence periods with maize at stages R2 and R5

Note. ${ }^{1} \mathrm{mg}$ EGA g ${ }^{-1}$ DM; EGA: equivalents of gallic acid; ${ }^{2} \mathrm{mg}$ RUT g ${ }^{-1}$ DM; RUT: rutin; DM: dry matter. ${ }^{\text {ns }}$ : not significant; mean values followed by the same lowercase letter in stage R2 do not differ by Tukey's test $(p \leq 0.05)$.

Table 1. Flavonoids from soybean plants submitted to coexistence periods with corn at two soybean planting densities collected at the R2 soybean stage

\begin{tabular}{|c|c|c|c|c|}
\hline \multirow{3}{*}{ Coexistence periods } & \multicolumn{4}{|c|}{ Flavonoids (mg RUT g ${ }^{-1} \mathrm{DM}$ ) } \\
\hline & \multicolumn{4}{|c|}{ Density (th pl ha ${ }^{-1}$ ) } \\
\hline & 175 & & 350 & \\
\hline Control & $1.26 \mathrm{a}$ & $\mathrm{A}$ & $1.15 \mathrm{a}$ & $\mathrm{A}$ \\
\hline VO-R8 & $1.11 \mathrm{a}$ & $A$ & $1.03 \mathrm{a}$ & A \\
\hline V2-R8 & $1.35 \mathrm{a}$ & $A$ & $1.28 \mathrm{a}$ & A \\
\hline V4-R8 & $1.17 \mathrm{a}$ & $\mathrm{A}$ & $1.12 \mathrm{a}$ & A \\
\hline $\mathrm{CV}(\%)$ & 13.50 & & & \\
\hline
\end{tabular}

Note. Means followed by the same lower-case letter in the column and upper-case letter in the row do not differ by Tukey's test $(\mathrm{p} \leq 0.05)$; th $\mathrm{pl} \mathrm{ha}{ }^{-1}$ : thousand plants $\mathrm{ha}^{-1}$; RUT: rutin; DM: dry matter; CV: coefficient of variation.

With regard to the saponin content, no interaction was observed between densities and coexistence periods in Experiment I (Figure 4). However, with regard to the coexistence periods, a tendency for an increase in the content of this metabolite could be observed when in competition with weeds at the two collection stages. The most significant increases were in the coexistence periods of V0-R8 and V4-R8, already in V2-R8 for both collection stages this content was lower in relation to the other periods, but remained larger than the control without competition. 


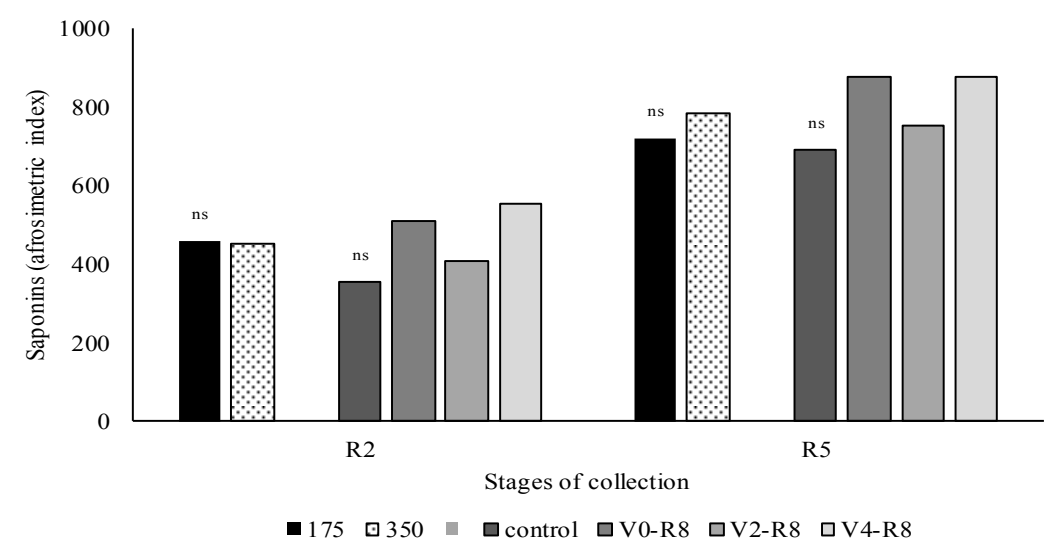

Figure 4. Saponin content of soybean plants submitted to two soybean planting densities (thousand plants $\mathrm{ha}^{-1}$ ) and different coexistence periods with corn at two stages of collection, R2 and R5

Note. ${ }^{\text {ns }}$ : not significant.

In Experiment I, it was possible to infer that the content of total phenols and flavonoids decreased when soybean was in competition with corn, but when the coexistence period started at the V2 soybean stage the content of these metabolites increased. In this experiment, the saponin content increased when soybean plants were in competition with corn, but when competition started at the V2 stage it decreased, but did not equal the control treatment which had no competition. These data show that the presence of weeds throughout the soybean growth cycle decreased the total phenol content, and as a consequence decreased flavonoids, which are phenols.

In Experiment II, with the pluck management of regrowth horseweed, the total phenol content was lower in the V0-R3 coexistence period, already the V0-R6 period, the presence of the horseweed increased total phenol content (Table 2). A similar result was reported for the flavonoid content in the V0-R2 and V0-R6 periods, where the presence of the horseweed increased this secondary metabolite. In the V0-R4 period, the presence of the horseweed decreased the flavonoid content (Table 2). With regard to saponin content, it increased when competition with horseweed occurred in V0-R3 and V0-R4, but when the competition extended from V0 to R6, the presence of weeds resulted in a $50 \%$ reduction in saponin content (Table 2 ).

Table 2. Total phenols, flavonoids and saponins in soybean plants grown without and with regrowth horseweed (Conyza spp.) in different coexistence periods with pluck management

\begin{tabular}{|c|c|c|c|c|c|c|c|c|c|}
\hline \multirow{3}{*}{ Coexistence periods } & & & & \multicolumn{3}{|c|}{ Pluck management } & & & \\
\hline & \multicolumn{3}{|c|}{$\begin{array}{c}\text { Total phenols } \\
\left(\mathrm{mg} \mathrm{EGA} \mathrm{g}^{-1} \mathrm{DM}\right)\end{array}$} & \multicolumn{3}{|c|}{$\begin{array}{c}\text { Flavonoids } \\
\left(\mathrm{mg} \mathrm{RUT} \mathrm{g}^{-1} \mathrm{DM}\right)\end{array}$} & \multicolumn{3}{|c|}{$\begin{array}{c}\text { Saponins } \\
\text { (Afrosimetric index) }\end{array}$} \\
\hline & Without & With & $\mathrm{p}$ value & Without & With & $\mathrm{p}$ value & Without & With & $\mathrm{p}$ value \\
\hline V0-R2 & 2.75 & 2.76 & 0.493 & 1.15 & 1.37 & 0.010 & 750.00 & 750.00 & 0.500 \\
\hline V0-R3 & 3.21 & 2.37 & 0.01 & 1.04 & 1.06 & 0.450 & 333.33 & 500.00 & $<0.001$ \\
\hline V0-R4 & 2.62 & 2.47 & 0.131 & 1.28 & 1.12 & 0.041 & 333.33 & 708.33 & 0.036 \\
\hline V0-R5 & 2.04 & 2.19 & 0.321 & 1.13 & 0.98 & 0.207 & 750.00 & 500.00 & 0.067 \\
\hline V0-R6 & 1.92 & 2.43 & 0.033 & 0.74 & 0.98 & 0.028 & 1000.00 & 458.33 & $<0.001$ \\
\hline
\end{tabular}

Note. Significant differences were based on the t-test using a 5\% level of significance.

With court management of regrowth horseweed plants, where competition continued through the root system, the content of total phenols was modified only in the V0-R3 coexistence period where the presence of weed decreased this metabolite (Table 3). The content of flavonoids increased during the V0-R2 and V0-R6 periods, and decreased during V0-R3 period (Table 3). With regard to saponin content, there was no difference between the presence or absence of horseweed in the coexistence periods (Table 3).

There are several factors that influence the secondary metabolism of plants, such as high plant densities (Rivoal et al., 2011), different relative proportions of weeds and the crop (Agostinetto et al., 2016), cultivars and growth conditions (John et al., 2016). In the soybean roots, the flavonoid content was reduced when in competition with 
weeds, which leads to a reduction in the number of root nodules, due to the flavonoids signaling to the symbiotic bacteria (Gal et al., 2015). For the soybean crop, the competition stress is comparable to that induced by biotic and abiotic factors (Agostinetto et al., 2016). Thus, it is possible that modifications in the secondary metabolites alter numerous plant characteristics, and, therefore, it is important to discover the possible causal agents in order to avoid them during crop production.

Table 3. Total phenols, flavonoids and saponins in soybean plants grown without and with regrowth horseweed (Conyza spp.) in different coexistence periods with court management

\begin{tabular}{|c|c|c|c|c|c|c|c|c|c|}
\hline \multirow{3}{*}{ Coexistence periods } & \multirow{2}{*}{\multicolumn{3}{|c|}{$\begin{array}{c}\text { Total phenols } \\
\left(\mathrm{mg} \mathrm{EGA} \mathrm{g}^{-1} \mathrm{DM}\right)\end{array}$}} & \multicolumn{3}{|c|}{ Court management } & & & \\
\hline & & & & \multicolumn{3}{|c|}{$\begin{array}{c}\text { Flavonoids } \\
\left(\mathrm{mg} \mathrm{RUT} \mathrm{g}^{-1} \mathrm{DM}\right)\end{array}$} & \multicolumn{3}{|c|}{$\begin{array}{c}\text { Saponins } \\
\text { (Afrosimetric index) }\end{array}$} \\
\hline & Without & With & $\mathrm{p}$ value & Without & With & $\mathrm{p}$ value & Without & With & $\mathrm{p}$ value \\
\hline V0-R2 & 2.19 & 2.55 & 0.069 & 0.83 & 1.13 & 0.003 & 750.00 & 875.00 & 0.268 \\
\hline V0-R3 & 2.41 & 2.08 & 0.002 & 1.12 & 0.95 & 0.034 & 416.66 & 499.99 & 0.324 \\
\hline V0-R4 & 2.80 & 2.54 & 0.166 & 1.25 & 1.08 & 0.113 & 416.66 & 416.66 & 0.500 \\
\hline V0-R5 & 2.53 & 2.10 & 0.087 & 1.25 & 1.00 & 0.115 & 500.00 & 625.00 & 0.178 \\
\hline V0-R6 & 2.62 & 2.62 & 0.489 & 0.90 & 1.19 & 0.003 & 333.33 & 416.66 & 0.067 \\
\hline
\end{tabular}

Note. Significant differences were based on the t-test using a 5\% level of significance.

The isoflavones are a group of flavonoids which, in soybean, are affected by the origin of the cultivars, in case seeds are affected by their weight and by environmental factors (Kim et al., 2012). Daidzin, daidzein, genistein, genistine and glycytine are isoflavonoids found in different soybean cultivars (John et al., 2016; Kim et al., 2012), and in different concentrations in plant organs, where the highest concentration is found in grains, followed by the leaves (Seo et al., 2017). The isoflavones, genistein and daidzein, are the most abundant and have anti-cancer properties (Pereira \& Cardozo, 2012). Therefore, any factor leading to a decrease in these compounds is undesirable from a human health perspective.

In addition to isoflavones, soybean contains numerous saponins that are a type of terpene. These are a diverse group of secondary metabolites with a wide range of activities with an important role in human health. In soybean, soysaponins are the main representatives (Tantry \& Khan, 2013). In Chinese soybean cultivars, 13 saponin components were detected, including the new $\alpha$ and $\beta$ groups, and groups A, DDMP and B (Takahassi et al., 2017). The concentration of these compounds is influenced by the origin of the genotypes, environmental factors such as location and year of cultivation, environmental conditions such as light, temperature, humidity and soil fertility and, when evaluated in seeds, is influenced by seed weight (Kim et al., 2012). With our results it was not possible to identify the types of compounds, since general tests were used, but the answer was possible to identify since in general there were changes in the secondary metabolism resulting from the competition.

The grain yield of soybean in Experiment I was not influenced by the planting density of the crop, but there was a significant difference between the coexistence periods with maize (Figure 5). When corn, considered as the weed in the experiment, was sown on the same day as the crop and remained until the end of the cycle (V0-R8), there was a reduction in yield of $36 \%$. Weeds that emerge before or at the same time as the crop have greater competitive potential in relation to the crop (Piasecki, 2015; Tironi et al., 2014).

For example, the weeds of the species Galinsoga parviflora, Digitaria horizontalis, Brachiaria decumbens, Amaranthus retroflexus, Bidens pilosa, Euphorbia heterophylla and others, in competition with soybeans throughout the crop cycle, reduced the grain yield by $30 \%$ (Marangoni et al., 2013). Soybean in competition with maize that emerged ten days earlier than or on the same day produced an average of $382 \%$ and $241 \%$ less than when maize emerged ten days after the crop (Piasecki, 2015). Soybean cultivars, when competing with corn at densities of 10 and 30 plants $\mathrm{m}^{-2}$ and sowed on the same day as the crop, showed a mean reduction in yield of $80 \%$ (Schneider et al., 2014).

Weeds that emerge before the crop have prior access to environmental resources and thus have morphological characteristics that increase their competitive potential in relation to the crop. When barley was in competition with ryegrass, the number of barley stems was 96.87 when weeds emerged 14 days after barley emerged, but when weeds emerged 14 days earlier, there were 18.47 barley stems (Tironi et al., 2014). 
Corn plants at density of 16 plants $\mathrm{m}^{-2}$, that emerged before or together with soybeans, presented a leaf area of $11.34 \mathrm{~cm}^{2}$; when they emerged after soybean, the same density of plants presented a leaf area of $2.21 \mathrm{~cm}^{2}$ due to competition imposed by soybean, indicating that plants which emerge after crop have low competitive potential compared to those emerging before or along with the crop (Marquardt et al., 2012). Longer intervals between desiccation and sowing of soybeans provide priority conditions for weed growth and, thus, weeds have a competitive advantage over the crop and have the greatest negative impact on yield (Rizzardi et al., 2003).

Weeds that emerge after crop are less competitive in terms of yield (Saraiva et al., 2013; Swanton et al., 2015; Tironi et al., 2014), since crop acts as a cultural control over species which diminishes the growth potential and competition of these, against crops. When sowing of corn occurred at the soybean V2 stage, the reduction in grain yield was $22 \%$, already in $\mathrm{V} 4$ the reduction was $4 \%$, not statistically different from the control without competition (Figure 5). The results demonstrate that the greatest reduction in soybean yield when competing with weeds occurs when competition starts at the beginning of crop development and at stage V2.

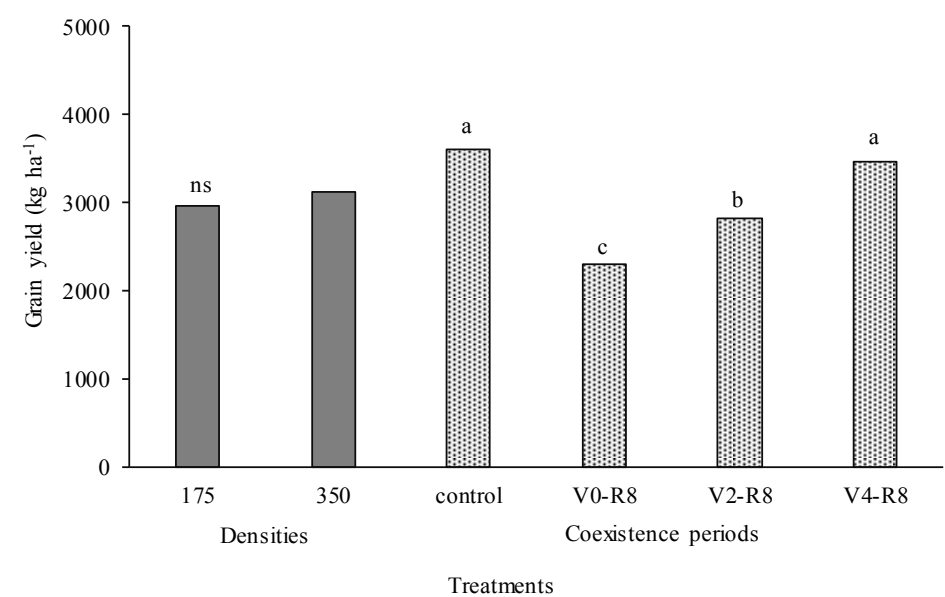

Figure 5. Soybean seed yield as a result of different sowing densities (thousand plants $\mathrm{ha}^{-1}$ ) and coexistence periods with corn in Experiment I

Note. ${ }^{\text {ns }}$ : not significant; means followed by the same lower-case letter in columns of the same color do not differ by Tukey's test $(\mathrm{p} \leq 0.05)$.

Soybean plants in the V4 stage possess a larger leaf area with subsequent greater shading of the soil, which suppresses the development of weeds in the vegetative canopy, and thus causes less interference with the crop. When Brachiaria brizantha, 'BRS Piata' and B. ruziziensis plants were sown 24 days after soybean emergence, the highest competitive effect of soybean cultivar M-8766 RR was observed on the weed, where the reduction in (Saraiva et al., 2013), so it is justified that by the greater development of the crop at 24 days than at 12 days.

In addition, the plant density of the crop significantly affects the speed of interlining (Balbinot Junior et al., 2016), which is directly related to the cultural suppression of weeds. In this study, the density of the crop did not significantly affect the yield. This happened because the soybean crop presents high plasticity, with the potential to compensate for the smaller number of plants with a greater number of pods and grains (Table 4).

The competition between crops and weed compromises the development of reproductive structures and, among them, the number of pods is the most responsive to changes caused by the stress of competition (Lamego et al., 2004; Trezzi et al., 2015). In this study, it was observed that the presence of corn reduced the number of pods and, consequently, the number of grains from soybean plants with all periods of competition, where the lowest soybean density showed the greatest reduction (Table 4). Competition throughout the soybean crop cycle reduced the number of pods by $40 \%$ and $24 \%$ at the densities of 175 and 350 th $\mathrm{pl} \mathrm{ha}^{-1}$, respectively. This corroborates the reduction of $36 \%$ reported by Lamego et al. (2004) when soybean was in competition for the whole cycle.

The results obtained can be associated to studies where different levels of infestation and weed origin were tested with different times of emergence, which affirms that competition reduces components of yield. The number of pods per plant was reduced in areas with weed infestation at low, medium and high levels (Silva et al., 2008). Soybean in competition with maize, originating from volunteer plants and clumps, showed an average number of 
pods of 10, 9.5 and 18.5, and number of grains of 22, 21 and 38 per plant when the corn emerged ten days earlier, the same day and ten days after the emergence of soybean, respectively (Piasecki, 2015).

These findings confirm the results obtained in the present study where competition with weeds resulted in the greatest reductions in the number of pods and grains in the competition started in the emergence of the crop, and that the competition initiated at the V4 stage presented the smallest reductions, since there was suppression by the crop of the weed species. Of the densities, 175,000 plants ha ${ }^{-1}$ was statistically higher than 350,000 plants ha $^{-1}$, with almost double the number of pods and grains in the control without competition (Table 4). This corroborates Balbinot Junior et al. (2016) in that, with a lower soybean density, there were four times more pods than with a higher density. This increase is related to the higher number of branches on the plants at low densities, which is directly related to the greater potential of nodes on the branches and, consequently, a greater number of pods (Mauad et al., 2010).

Table 4. Total soybean pods and seeds with different sowing densities of soybean and different coexistence periods with corn in the Experiment I

\begin{tabular}{|c|c|c|c|c|c|c|c|}
\hline \multirow{3}{*}{ Coexistence periods } & \multicolumn{3}{|c|}{ Total pods } & \multicolumn{4}{|c|}{ Total grains } \\
\hline & \multicolumn{3}{|c|}{ Densities (th $\mathrm{pl} \mathrm{ha}^{-1}$ ) } & \multicolumn{4}{|c|}{ Densities (th $\mathrm{pl} \mathrm{ha}^{-1}$ ) } \\
\hline & 175 & & 350 & 175 & & 350 & \\
\hline control & 72.77 & $\begin{array}{ll}\mathrm{a} & \mathrm{A}\end{array}$ & 39.23 ab $B$ & 172.90 & a $\mathrm{A}$ & $93.95 \mathrm{ab}$ & $\mathrm{B}$ \\
\hline V0-R8 & 43.31 & c A & 29.72 b $\quad B$ & 102.04 & c A & $69.15 \mathrm{~b}$ & B \\
\hline V2-R8 & 47.98 & c A & $37.64 \mathrm{ab} \quad \mathrm{B}$ & 110.98 & c A & $86.97 \mathrm{ab}$ & B \\
\hline V4-R8 & 59.73 & b A & 40.61 a $B$ & 143.73 & b A & $94.31 \mathrm{a}$ & B \\
\hline $\mathrm{CV}(\%)$ & \multicolumn{3}{|c|}{ Densities: 17.71} & \multicolumn{4}{|c|}{ Densities: 19.89} \\
\hline $\mathrm{CV}(\%)$ & \multicolumn{3}{|c|}{ Treatament: 11.27} & \multicolumn{4}{|c|}{ Treatament: 11.38} \\
\hline
\end{tabular}

Note. th $\mathrm{pl} \mathrm{ha}^{-1}$ : thousand plants $\mathrm{ha}^{-1}$. Means followed by the same lower-case letter in the column and upper-case letter in the row do not differ by Tukey's test $(\mathrm{p} \leq 0.05)$; CV: coefficient of variation.

The thousand seed weight did not show a significant difference between the densities and the evaluated periods (Figure 6). The results of this experiment indicate that the emergence of corn at more advanced stages of soybean causes little interference on the crop compared when corn emerges along with the crop. In addition, the density of 175 th $\mathrm{pl} \mathrm{ha}^{-1}$ makes soybean crops more susceptible to competition from weeds.

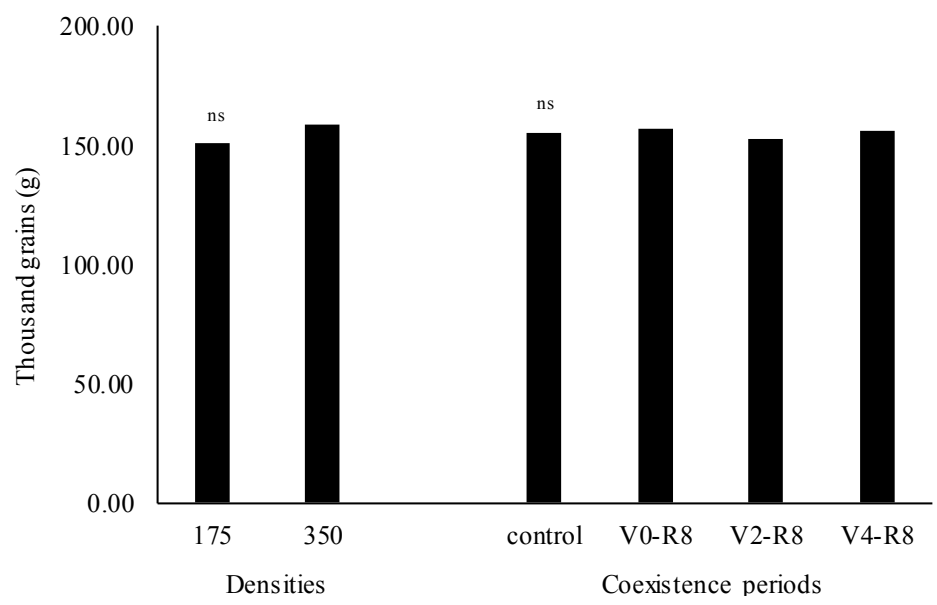

Figure 6. Thousand seed weight of soybean submitted to different sowing densities (thousand plants ha ${ }^{-1}$ ) and different coexistence periods with maize in Experiment I

Note. ${ }^{\text {ns }}$ : not significant.

Experiment II did not show a significant interaction between soybean seed yield and the regrowth management of horseweed and the coexistence periods (Figure 7). Although regrowth showed advanced development when weeds 
were managed before sowing of the crop, the resumption of growth during soybean cultivation was not sufficient to significantly interfere with crop yield. Currently, the conditions of bad management of weeds, that is, the lack of control of the species during the winter preceding the soybean crop, maintains the presence of these plants with great development in the harvest of the winter cereals. This cut made by the harvester, stimulates a later regrowth during the summer crop. This situation has become very common in the northern region of Rio Grande do Sul, which prompts the study of the influence of this regrowth at more advanced stages, that is, in the reproductive phase of the soybean crop.

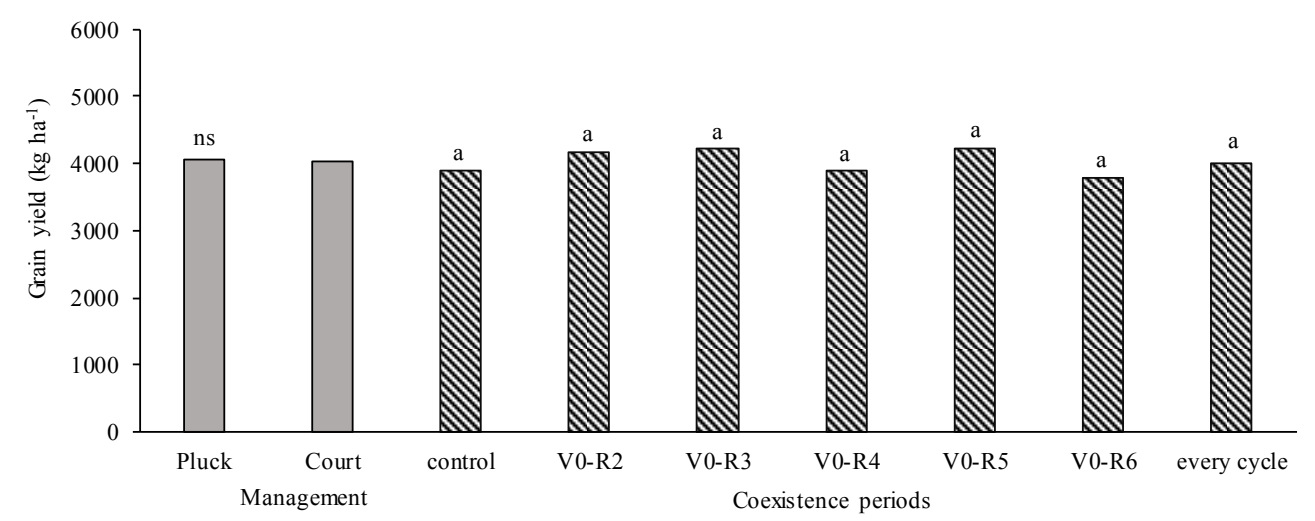

Figure 7. Grain yield of soybean submitted to different coexistence periods with regrowth horseweed managed by pluck or court in Experiment II

Note. $n s$ : not significant; means followed by the same lower-case letter in columns of the same color do not differ by Tukey's test $(\mathrm{p} \leq 0.05)$.

It is likely that weed regrowth during soybean cultivation may have a greater negative effect since the plants already have an established root system, which gives them greater competition potential after the resumption of growth. Under the conditions of this experiment, it was possible to observe that the horseweed regrowth during the soybean crop did not reduce the seed yield.

The management carried out on horseweed at different stages did not modify the competitive potential of the weed against the crop, even though the root and some leaves were maintained so that the competition continued until the end of the cycle. This competition was shown not to be enough to interfere with crop grain yield. Also, it was not possible to observe a change in the yield from the soybean stage where the management was performed compared to the control, and when there was competition for the entire growth cycle.

The components of total pods, total grains and weight of a thousand grains did not present significant differences between the management and the coexistence periods of the soybean with the horseweed (Table 5). 
Table 5. Yield components of total pods (TP), total seed (TG) and one thousand seed weight (OTG) of soybeans submitted to different coexistence periods with regrowth horseweed managed by pluck or court in Experiment II

\begin{tabular}{|c|c|c|c|}
\hline \multirow{2}{*}{$\begin{array}{l}\text { Source of variation } \\
\text { Management }\end{array}$} & \multicolumn{3}{|c|}{ Yield components } \\
\hline & TP & TG & OTG \\
\hline Pluck & 45.49 ns & $116.29^{\mathrm{ns}}$ & $150.00 \mathrm{~ns}$ \\
\hline Court & 44.85 & 115.11 & 152.00 \\
\hline $\mathrm{CV}(\%)$ & 17.18 & 17.91 & 7.00 \\
\hline \multicolumn{4}{|l|}{ Coexistence periods } \\
\hline control & $46.42^{\text {ns }}$ & $119.49^{\mathrm{ns}}$ & $154.00^{\mathrm{ns}}$ \\
\hline V0-R2 & 48.44 & 124.29 & 154.50 \\
\hline V0-R3 & 44.25 & 114.44 & 156.52 \\
\hline V0-R4 & 44.63 & 114.92 & 157.25 \\
\hline V0-R5 & 41.87 & 105.36 & 154.26 \\
\hline V0-R6 & 45.08 & 115.27 & 155.18 \\
\hline every cycle & 45.51 & 116.13 & 156.25 \\
\hline $\mathrm{CV}(\%)$ & 8.41 & 9.52 & 9.00 \\
\hline
\end{tabular}

Note. OTG in grams; ${ }^{\text {ns: }}$ not significant; $\mathrm{CV}$ : coefficient of variation.

\section{Conclusion}

Corn that develops after soybean V4 stage and regrowth horseweed during cultivation do not adversely affect secondary metabolism, grain yield or soybean yield components.

\section{References}

Agostinetto, D., Oliveira, C., Langaro, A. C., Nohatto, M. A., \& Manica-Berto, R. (2016). Change in physiological features in ryegrass biotypes in competition with soybean due resistance to glyphosate. Planta Daninha, 34(3), 517-526. https://doi.org/10.1590/s0100-83582016340300012

Balbinot Junior, A. A., Werner, F., Ferreira, A. S., Mandarino, J. M. G., Debiasi, H., \& Franchini, J. C. (2016). Desempenho agronômico da soja em diferentes densidades de plantas e épocas de aplicação de nitrogênio em sistema de plantio direto. Revista de Ciências Agrárias, 59(2), 132-137. https://doi.org/10.4322/rca.2231

Broz, A. K., Broeckling, C. D., De-La-Pena, C., Lewis, M. R., Greene, E., Callaway, R. M., ... Vivanco, J. M. (2010). Plant neighbor identity influences plant biochemistry and physiology related to defense. BMC Plant Biology, 10(115), 1-14. https://doi.org/10.1186/1471-2229-10-115

EMBRAPA (Empresa Brasileira de Pesquisa Agropecuária). (2017). Normais Climatológicas (1961/1990) Passo Fundo-RS. Retrieved from http://www.cnpt.embrapa.br/pesquisa/agromet/app/principal/normais.php

Farmacopéia. (2010). Farmacopéia Brasileira. Brasília: Anvisa.

Fehr, W. R., \& Caviness, C. E. (1977). Stages of soybean development (p. 11). Ames: Iowa State University of Science and Techonology.

Gal, J., Afifi, M., Lee, E., Lukens, L., \& Swanton, C. J. (2015). Detection of neighboring weeds alters soybean seedling roots and nodulation. Weed Science, 63(4), 888-900. https://doi.org/10.1614/WS-D-15-00039.1

Josipovic, A., Sudar, R., Sudaric, A., Jurkovic, V., Kocar, M. M., \& Kulundzic, A. M. (2016). Total phenolic and total flavonoid content variability of soybean genotypes in eastern Croatia. Croatian Journal of Food Science and Technology, 8(2), 60-65. https://doi.org/10.17508/CJFST.2016.8.2.04

John, K. M. M., Natarajan, S., \& Luthria, D. L. (2016). Metabolite changes in nine different soybean varieties grown under field and greenhouse conditions. Food Chemistry, 211(15), 347-355. https://doi.org/10.1016/ j.foodchem.2016.05.055

Kim, E. H., Ro, H. M., Kim, S. L., Kim, H. S., \& Chung, I. M. (2012). Analysis of isoflavone, phenolic, soyasapogenol and tocoferol compounds in soybean [Glycine max (L.) Merrill] germplasms of different seed weights and origins. Journal of Agricultural Food Chemistry, 60(23), 6045-6055. https://doi.org/ $10.1021 / \mathrm{jf3} 00463 \mathrm{f}$ 
Lamego, F. P., Fleck, N. G., Bianchi, M. A., \& Schaedler, C. E. (2004). Tolerância à interferência de plantas competidoras e habilidade de supressão por genótipos de soja-II Resposta de variáveis de produtividade. Planta Daninha, 22(4), 491-498. https://doi.org/10.1590/S0100-83582004000400002

Marquardt, P., Krupke, C., \& Johnson, W. G. (2012). Competition of transgenic volunteer corn with soybean and the effect on western corn rootworm emergence. Weed Science, 60(2), 193-198. https://doi.org/10.1614/ WS-D-11-00133.1

Mauad, M., Silva, T. L. B., Neto, A. I. A., \& Abreu, V. G. (2010). Influência da densidade de semeadura sobre características agronômicas na cultura da soja. Revista Agrarian, 3(9), 175-181.

Marangoni, R. E., Jakelaitis, A., Tavares, C. J., Rezende, B. P. M., Mello Filho, O. L., \& Cunha, P. C. R. (2013). Effect of weed interference on soybean cultivars at two sowing times. Planta Daninha, 31(3), 511-519. https://doi.org/10.1590/S0100-83582013000300003

Pereira, R. J., \& Cardoso, M. Das G. (2012). Metabólitos secundários vegetais e benefícios antioxidantes. Journal of Biotechnolofy and Biodiversity, 3(4), 146-152.

Piasecki, C. (2015). Interferência e controle de milho voluntário resistente ao glifosato na cultura da soja (Master's thesis, University of Passo Fundo, Passo Fundo, Brazil). Retrieved from http://tede.upf.br/ jspui/handle/tede/1270

Pioneer. (2017). Cultivares de Soja. Retrieved from http://www.pioneersementes.com.br/soja/central-de-produtos

Radosevich, S. R., Holt, J. S., \& Ghersa, C. M. (2007). Ecology of weeds and invasive plants: Relationship to agriculture and natural resource management (3rd ed.). New York: Willey. https://doi.org/10.1002/ 9780470168943

Rizzardi, M. A., Fleck, N. G., \& Agostinetto, D. (2003). Nível de dano econômico como critério para controle de picão-preto em soja. Planta Daninha, 21(2), 273-282. https://doi.org/10.1590/S0100-83582003000200013

Rivoal, A., Fernandez, C., Greff, S., Montes, N. \& Vila, B. (2011). Does competition stress decrease allelopathic potential? Biochemical Systematics and Ecology, 39(4-6), 401-407. https://doi.org/10.1016/j.bse.2011. 05.017

Ribeiro, A. B. M., Bruzi, A. T., Zuffo, A. M., Zambiazzi, E. V., Soares, I. O., Vilela, N. J. D., ... Moreira, S. G. (2017). Productive performance of soybean cultivars grown in different plant densities. Ciência Rural, 47(7), 1-8. https://doi.org/10.1590/0103-8478cr20160928

Saraiva, A. S., Erasmo, E. A. L., Mata, J. F., Dornelas, B. F., Dornelas, D. F., \& Silva, J. I. C. (2013). Density and sowing season of two Brachiaria species on the soybean culture. Planta Daninha, 31(3), 569-576. https://doi.org/10.1590/S0100-83582013000300009

Schneider, T., Rockenbach, A. P., \& Bianchi, M. A. (2014). Alteração do período anterior à interferência da soja na presença de plantas voluntárias de milho. Revista Brasileira de Herbicidas, 13(2), 80-87. https://doi.org/10.7824/rbh.v13i2.258

Seo, W. D., Kang, J. E., Choi, S.-W., Lee, K.-S., Lee, M.-J., Park, K.-D., \& Lee, J. H. (2017). Comparison of nutritional components (isoflavone, protein, oil, and fatty acid) and antioxidant properties at the growth stage of different parts of soybean [Glycine max (L.) Merrill]. Food Science and Biotechnology, 26(2), 339-347. https://doi.org/10.1007/s10068-017-0046-x

Silva, A. F., Ferreira, E. A., Concenço, G., Ferreira, F. A., Aspiazú, I., Galon, L., ... Silva, A. A. (2008). Densidade de plantas daninhas e épocas de controle sobre os componentes de produção de soja. Planta Daninha, 26(1), 65-71. https://doi.org/10.1590/S0100-83582008000100007

Silva, D. R. O., Agostinetto, D., Vargas, L., Langaro, A. C., \& Duarte, T. V. (2014). Habilidade competitiva, alterações no metabolismo secundário e danos celulares de soja competindo com Conyza bonariensis resistente e suscetível a glyphosate. Planta Daninha, 32(3), 579-589. https://doi.org/10.1590/ S0100-83582014000300014

Streck, E. V., Kampf, N., Dalmolin, R. S. D., Klamt, E., Nascimento, P. C., Schneider, P., ... Pinto, L. F. S. (2008). Solos do Rio Grande do Sul (2nd ed.). Porto Alegre: EMATER, Brazil.

Swanton, C. J., Nkoa, R., \& Blackshaw, R. E. (2015). Experimental methods for crop weed competition studies. Weed Science, 63(sp1), 2-11, 2015. https://doi.org/10.1614/WS-D-13-00062.1

Taiz, L., \& Zeiger, E. (2013). Fisiologia vegetal (5th ed.). Porto Alegre: Artmed. 
Takahassi, Y., Li, X. H., Qiu, L. J., Tsukamoto, C., \& Wang, K. J. (2017). Identification of saponin composition and their geographical distribution in Chinese cultivated soybean (Glycine max). Euphytica, 213(8), 1-16. https://doi.org/10.1007/s10681-017-1956-7

Tantry, M. A., \& Khan, I. A. (2013). Saponins from Glycine max Merrill (soybean). Fitoterapia, 87, 49-56. https://doi.org/10.1016/j.fitote.2013.03.021

Tironi, S. P., Galon, L., Silva, A. F. da, Fialho, C. M. T., Rocha, P. R. R., Faria, A. T., ... Radunz, A. L. (2014). Época de emergência de azevém e nabo sobre a habilidade competitiva da cultura da cevada. Ciência Rural, 44(9), 1527-1533. https://doi.org/10.1590/0103-8478cr20131633

Trezzi, M. M., Vidal, R. A., Patel, F., Miotto, J. R. E., Debastiani, F., Balbinot Jr., A. A., \& Mosquen, R. (2015). Impact of Conyza bonariensis density and establishment period on soybean grain yield, yield components and economic threshold. Weed Research, 55(1), 34-41. https://doi.org/10.1111/wre.12125

\section{Copyrights}

Copyright for this article is retained by the author(s), with first publication rights granted to the journal.

This is an open-access article distributed under the terms and conditions of the Creative Commons Attribution license (http://creativecommons.org/licenses/by/4.0/). 